\title{
Original article (Orijinal araştırma) \\ Oxidative effects of boric acid on different developmental stages of Drosophila melanogaster Meigen, 1830 (Diptera: Drosophilidae) ${ }^{1}$
}

\author{
Drosophila melanogaster Meigen, 1830 (Diptera: Drosophilidae)'in farklı gelişme \\ dönemleri üzerine Borik asitin oksidatif etkileri
}

\author{
Eda GÜNEŞ ${ }^{*}$
}

\section{Ender BÜYÜKGÜZEL ${ }^{3}$}

\section{Summary}

Synthetic organic insecticides are widely used to combat agricultural pests. Boric acid has a great importance in pest management because it has less toxic effect on non-target organisms compared to other organic chemical insecticides. For this purpose, the fruit fly Drosophila melanogaster Meigen, 1830 (Diptera: Drosophilidae) was reared from first stage larvae on an artificial diet containing boric acid at 10, 100, 200 or $300 \mathrm{mg} / \mathrm{L}$ to adult stage. The effect of boric acid on important oxidative stress indicators such as lipid peroxidation product of malondialdehyde contents (MDA) and protein oxidation products of protein carbonyl contents (PCO) and detoxification enzyme activity of glutathione S-transferase (GST) in the third stage larvae, pupae, adults and eggs of $D$. melanogaster were investigated. All boric acid concentrations significantly increased MDA content in third stage larva. When the adults from the larvae reared on $300 \mathrm{mg} / \mathrm{L}$ of dietary BA were also fed with high BA concentration for a 10-day period, MDA and PCO contents of male and female adults were considerably went up in comparison to control. MDA and PCO content in the eggs of these females were hugely increased. The rise in PCO content of the eggs was 31-fold relative to control. Our results indicate that BA feeding at high concentrations in all developmental stages of $D$. melanogaster is more effective on oxidative stress indicators and detoxification enzyme.

Keywords: Boric acid, Drosophila melanogaster, oxidative stress

\section{Özet}

Tarımsal zararlılar ile mücadelede sentetik organik insektisitler yoğun olarak kullanılmaktadır. Borik asit organik kimyasal insektisitlere göre hedef olmayan organizmalara karşı daha düşük toksisiteye sahip olması nedeniyle önem taşımaktadır. Bu amaçla çalışmamızda meyve sineği Drosophila melanogaster Meigen,1830 (Diptera: Drosophilidae)'in birinci dönem larvaları borik asitin farklı konsantrasyonlarını (10, 100, 200 ve 300 mg/L) içeren yapay besinler ile yetiştirilmiştir. Drosophila melanogaster' in üçüncü dönem larva, pupa, ergin dönemleri ve yumurtalarında oksidatif stresin önemli indikatörleri olan lipid peroksidasyonu ürünü malondialdehid (MDA) ve protein oksidasyon ürünü protein karbonil miktarları (PCO) ile detoksifikasyon enzimi glutatyon-S-transferaz (GST) aktivitesi üzerine etkisi incelenmiştir. Borik asitin denenen konsantrasyonlarını içeren yapay besinler ile yetiştirilen $D$. melanogaster' in üçüncü dönem larvalarının MDA miktarı önemli derecede artmıştır. Yüksek borik asit ile yetiştirilen erginlerin 10 gün süreyle $300 \mathrm{mg} / \mathrm{L}$ borik asit içeren besin ile beslenilmesi sonucunda kontrol besinine göre dişi ve erkek bireylerde MDA ve PCO miktarları önemli derecede artmıştır. Bu dişilerin yumurtalarındaki MDA, PCO miktarları ve GST aktivitesi önemli derecede artarken, PCO miktarındaki artış yaklaşık 31 katı oranında olmuştur. Sonuçlarımız, borik asitin yüksek konsantrasyonlarıyla beslenen $D$. melanogaster'in tüm gelişme dönemlerindeki oksidatif stres indikatörleri ve detoksifikasyon enzimi üzerine oldukça etkili olduğunu göstermiştir.

Anahtar sözcükler: Borik asit, Drosophila melanogaster, oksidatif stres

\footnotetext{
${ }^{1}$ This study was presented as oral presentation at The Second National Molecular Biology and Biotechnology Congress (15-18 November 2012, Antalya, Turkey) and published as abstract in the abstracts book.

${ }^{2}$ Konya Necmettin Erbakan University, Faculty of Tourism, Department of Gastronomy and Culinary Arts, 42300, Konya, Turkey

${ }^{3}$ Bülent Ecevit University, Faculty of Arts and Science, Department of Molecular Biology and Genetics, 67100, Zonguldak, Turkey

* Corresponding author (Sorumlu yazar) e-mail: egunes@konya.edu.tr

Received (Alınış): 27.09.2016 Accepted (Kabul ediliş): 18.11.2016

Published Online (Çevrimiçi Yayın Tarihi): 04.01.2017
} 


\section{Introduction}

The use of chemical insecticides and their synthetic analogs to fight insects harmful agriculture is gradually increasing. Excessive and misdirected use of these substances harm the environment having negative effects on both target and non-target organisms. Innovative studies try to develop alternative control methods centering on the use of compounds and elements (e.g. B), which have lower toxicity to the environment, humans and other species, and do not have direct impacts on organisms.

Boron, a beneficial bioactive element for many organisms, is classified in a different group (Group D) than boron oxide and boric acid $\left(\mathrm{BA}, \mathrm{H}_{3} \mathrm{BO}_{3}\right.$ ) (Anonymous, 2004). According to the results of toxicity studies, BA used for various medical and agricultural purposes has negative effects on animals, but is less toxic to honey bees, birds, fish, aquatic organisms, beneficial insects that are biological control agents and mammals when used in low doses (EFSA, 2004). BA is used on organisms such as ants, cockroaches and mosquitos as a registered inorganic insecticide having a sterilizing effect and also affecting digestion acting as a stomach toxin (Cochran, 1995). BA increases in the amount of consumption stimulating nutrient intake and forms complexes with carbohydrates, nucleotides and vitamins causing insufficient uptake of these nutrients (Xue \& Barnard, 2003). For a long time BA has been used alone or in complex for the control of vermin (Xue \& Barnard, 2003). The use of substances which have effects on a relatively narrow group and are less toxic with different activity for controlling insects is important for organisms in the food chain. Having knowledge of the effects of chemicals used will allow minimization of negative effects on beneficial non-target insects, biological control agents humans, and the environment. The oxidative effect of BA on biochemical parameters and detoxification capacity of Drosophila melanogaster Meigen, 1830 (Diptera: Drosophilidae) has not been determined. Also, aging mechanisms subject to nutrient-induced oxidative stress in organisms exposed to pesticides have not been studied.

Reactive oxygen species may be generated in organisms as byproducts during normal metabolic activities or as a result of exposure to the substances causing various chemical or environmental pollution (Felton \& Summers, 1995). These radicals impede metabolic processes and cause oxidative damage in organisms damaging cellular components, such as fatty acids, proteins, carbohydrates, enzymes, nucleic acids, hormones and neurotransmitters (Hermes-Lima \& Zenteno-Savin, 2002). For instance, they cause damage changing structures of the enzymes which produce or annihilate reactive oxygen species (ROS) (Giordano et al., 2007). Toxic or harmful chemical substances cause oxidative damage leading to lipid peroxidation, protein and enzyme oxidation and increased level of cellular glutathione in insect tissues (Ahmad, 1995). The increase in the level of malondialdehyde (MDA), which is an important aldehyde derivative being a final product of the reactions known as lipid peroxidation reactions, and the generation of protein carbonyl (PCO) products as a result of oxidation of proteins by ROS and covalent modification of proteins are used as indicators in the assessment of oxidative effect (Evans et al., 1999; Gülbahar, 2007).

There is an antioxidant defense system which is responsible for annihilating or counteracting endogenous or exogenous reactive chemicals in organisms. The antioxidant mechanism also activates in insect tissues in response to stress and allows insects to survive under chemically unsuitable environmental conditions (Hyršl et al., 2007). There is a tissue-specific antioxidant defense mechanism which consists of antioxidant enzymes and substances in adipose tissue and midgut of insects (Barbehenn \& Stannard, 2004). Superoxide dismutase (SOD), catalase (CAT), glutathione peroxidase (GPx), glutathione S-transferase (GST), glutathione reductase (GR), ascorbate peroxidase, thioredoxin peroxidase, disulfide reductase, and methionine sulfoxide reductase are the antioxidant enzymes found in insects (Missirlis et al., 2003).

Organisms protect themselves from harmful effects of environmental stress depending on their detoxification capacities (Vasseur \& Leguille, 2004). GST which is responsible for insecticide resistance and detoxication of xenobiotics functions as an antioxidant enzyme with its peroxidase-like activity (Krishnan \& Kodrik, 2006). GST enzymes in invertebrates and vertebrates constitute a group of multifunctional detoxification enzymes neutralizing toxic effects of electrophilic substances by means of phase II detoxification system of reactive metabolites which are produced by microsomal oxidation and 
which conjugate xenobiotic with glutathione in order to transform them into their less toxic forms (Vontas et al., 2001). Researches have shown that insects have GST and may increase their GPx-like activity as a physiological adaptation against toxic substances. Also, there are studies showing that this activity varies between different stages of insects (Peric-Mataruga et al., 1997).

In this research, assessed how antioxidant defense systems of $D$. melanogaster, an organism not directly harmful to agriculture (Uysal \& Şişman, 2003), is affected when feed on BA and if BA has an effect on the antioxidant defense system in association with aging. Previous studies were conducted in order to determine the effects of BA and other B-containing compounds on survival and development of insects in terms of stimulation of nutrient intake (Hyršl et al., 2007; Durmuş \& Büyükgüzel, 2008). For this purpose, $D$. melanogaster was studied because it is an ectodermic organism with known quantitative nutrient needs, a short life span and is a model organism used for biochemical and physiological studies (Keser, 2010). In the study, changes in the activities of three important indicators for oxidative stress, MDA (a product of lipid peroxidation), PCO (a product of protein oxidation) and GST (a detoxification enzyme), were examined in third stage larvae, pupae and adults of insects fed on larval nutrient containing $\mathrm{BA}$, which has a low toxicity to non-target organisms.

\section{Materials and Methods}

\section{Drosophila melanogaster culture}

Culture of $D$. melanogaster ( $\mathrm{W}^{1118}$, wild type) was allowed to feed on an artificial nutrient $(8 \mathrm{~g}$ agar, $20 \mathrm{~g}$ D-sucrose, $11.8 \mathrm{~g}$ dry yeast, $0.8 \mathrm{~g}$ L-ascorbic acid, nipagin $3.5 \%$ solution, $36 \mathrm{~g}$ mashed potatoes, $1000 \mathrm{ml}$ of distilled water, heated to dissolve the agar) containing potato and sucrose under non-sterile conditions in $250 \mathrm{ml}$ glass bottles (Lesch et al., 2007). The insect culture was exposed to $25 \pm 2^{\circ} \mathrm{C}, 60$ $70 \%$ relative humidity, and $12 \mathrm{~h}$ photoperiod in a Nüve cooled incubator.

\section{Boric acid treatment}

BA $\left(99 \%, \mathrm{H}_{3} \mathrm{BO}_{3}\right)$ provided by the National Boron Research Institute, Ankara, Turkey was used in feeding experiments. BA was added to $1000 \mathrm{ml}$ of the artificial nutrient in 10, 100, 200, $300 \mathrm{mg}$ doses dissolved in water before the agar set. This concentration range was based on the studies conducted on various organisms using B and BA (Massie, 1994; Yang et al., 2000; Cisneros et al., 2002; Gore et al., 2004; Ali et al., 2006; Xue et al., 2006; Espinoza-Navarro et al., 2009), and because it would allow D. melanogaster to complete its development until the adult stage in pre-feeding experiments.

\section{Feeding experiments}

Newly hatched insects were raised until the adult stage with nutrients containing specified concentrations of BA. MDA and PCO levels, and GST activity were recorded during the last (third) larva, pupa and adult stages. Following this process, the adult individuals raised with various concentrations of BA from their larva stage were allowed to feed on various BA concentrations for $10 \mathrm{~d}$ in a second experimental setup, and the adult individuals raised with various BA concentrations from their larva stage were allowed to feed on BA-free nutrient for $10 \mathrm{~d}$ in a third experimental setup (Figure 1). MDA and PCO levels, and GST activity in adults and in the eggs of the females raised with adjusted concentrations of BA and in adults allowed to feed on BA-free nutrient for $10 \mathrm{~d}$ after they reach the adult stage (male and female) were determined. The experiments were conducted for $10 \mathrm{~d}$ of the adult stage because that it is the ideal period for reproductive efficiency (Kaya et al., 2009).

\section{Specimen preparation and biochemical analysis}

The specimens were extracted using cold homogenization buffer $(1.15 \%$ potassium chloride, $25 \mathrm{mM}$ dipotassium hydrogen phosphate, $5 \mathrm{mM}$ ethylene diamine tetraacetic acid, $2 \mathrm{mM}$ phenylmethylsulfonyl, $2 \mathrm{mM}$ dithiothreitol, $\mathrm{pH} 7.4$ ) in $+4^{\circ} \mathrm{C}$ in an ultrasonic homogenizer (Bandelin Sonoplus, HD2070, Berlin, Germany). The specimens were kept at $-80^{\circ} \mathrm{C}$ until analysed. The experiments were repeated four times using 20 larvae, 20 pupae, 20 females and 20 male adults (Taşkın et al., 2007), and 200 eggs for biochemical analysis. 
The levels of MDA which is a final product of lipid peroxidation in the specimens reacted with thiobarbituric acid at $532 \mathrm{~nm}$ were measured based on the method used by Jain \& Levine (1995). The coefficient of $1.56 \times 10^{5} \mathrm{M}^{-1} \mathrm{~cm}^{-1}$ was used and the level of MDA was calculated as nmol/mg protein.

Determination of protein carbonyl followed the method of Levine et al. (1994) with minor modifications (Krishnan \& Kodrik, 2006): 2,4-dinitrophenylhydrazone, a stable compound formed by carbonyl groups in proteins, and 2,4-dinitrophenylhydrazine were calculated as nmol/mg protein at $370 \mathrm{~nm}$ using the coefficient of $22.0 \mathrm{M}^{-1} \mathrm{~cm}^{-1}$ in a strong acidic medium.

Glutathione S-transferase (EC 2.5.1.18) activity was determined by the method of Habig et al. (1974), as the amount of thioethers produced per $1 \mathrm{mg}$ of total protein in the supernatant at $340 \mathrm{~nm}\left(\varepsilon_{340}\right.$ : $9.6 \mathrm{mM} / \mathrm{cm}$ ) for $1 \mathrm{~min}$.

The enzyme specific activity was calculated as $\mu \mathrm{mol} / \mathrm{mg}$ protein $/ \mathrm{min}$. Total protein was determined at $600 \mathrm{~nm}$ by the Folin-Lowry method (Lowry et al., 1951). A Shimadzu 1700, UV/VIS (Kyoto, Japan) spectrophotometer was used for the determination of MDA and PCO levels, the total amount of protein, and GST activity. All chemicals used in the experiments where analytical grade.

\section{Data evaluation}

In order to determine the effects of BA in various concentrations on D. melanogaster, one-way analysis of variance was used for MDA and PCO levels and GST activity, and LSD test was used to compare means (SPSS, 1997). The Kruskal-Wallis test was used to determine differences between respective MDA and PCO levels and GST activities of larva-pupa-adult stages at each BA concentration, and the Mann Whitney $U$ test for differences between male and female adults at each BA concentration. The significance level used was $P \leq 0.05$.

\section{Results and Discussion}

For $D$. melanogaster raised until the adult stage with BA concentrations added to the nutrient medium, the effects of different BA concentrations on MDA and PCO levels and GST activity in last (third) stage larvae, pupae and adults (male and female) are shown in Tables 1 to 3.

\section{The experimental setup}

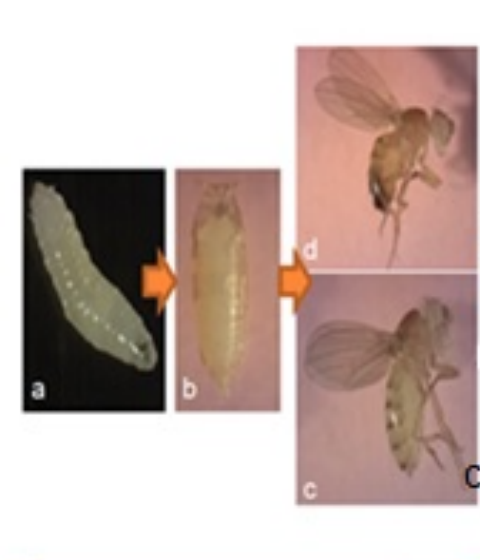

Feeding with BA concentrations BA
3. The experimental setup
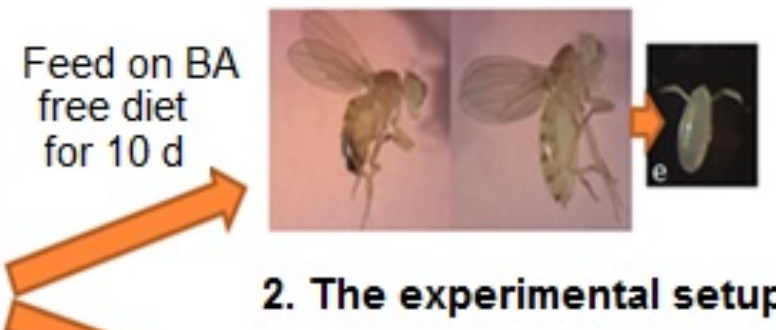

2. The experimental setup

Feed on

oncentrations for $10 \mathrm{~d}$

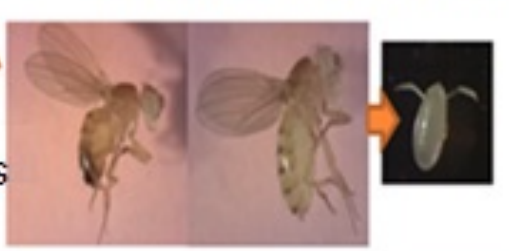

BA effects after the adult stage

Figure 1. The insects with different BA concentrations before and after feeding experiments; a. last larval stage b. pupae, c. female, d. male e. egg. 
Table 1. Malondialdehyde (MDA) levels in various developmental stages of Drosophila melanogaster raised with artificial nutrient containing various concentrations of boric acid

\begin{tabular}{|c|c|c|c|c|}
\hline \multirow{3}{*}{$\begin{array}{l}\text { Boric acid } \\
\text { (mg/Liter) }\end{array}$} & \multicolumn{4}{|c|}{$\begin{array}{c}\text { MDA } \\
\left(\mathrm{nmol} / \mathrm{mg} \text { protein) }^{\star}{ }_{(\mathrm{S} . \mathrm{E})}^{\dagger \#}\right.\end{array}$} \\
\hline & \multirow{2}{*}{ Third stage larvae } & \multirow{2}{*}{ Pupae } & \multicolumn{2}{|c|}{ Adult } \\
\hline & & & Female & Male \\
\hline $0.0^{\S}$ & $0.13 \pm 0.08 a A$ & $0.06 \pm 0.01 \mathrm{aAB}$ & $0.04 \pm 0.03 a \mathrm{aB}$ & $0.04 \pm 0.01 \mathrm{aB}$ \\
\hline 10 & $0.29 \pm 0.02 \mathrm{bAB}$ & $0.04 \pm 0.01 \mathrm{aA}$ & $0.48 \pm 0.12 \quad b B$ & $0.04 \pm 0.01 \mathrm{aA}$ \\
\hline 100 & $0.26 \pm 0.56 \mathrm{bAB}$ & $0.05 \pm 0.02 a A$ & $0.37 \pm 0.07 \quad b B$ & $0.12 \pm 0.03 a b A B$ \\
\hline 200 & $0.34 \pm 0.03 b c A B$ & $0.07 \pm 0.02$ aA & $0.16 \pm 0.02 a b A B$ & $0.30 \pm 0.05 \mathrm{bB}$ \\
\hline 300 & $0.41 \pm 0.05 \mathrm{bcA}$ & $0.11 \pm 0.03 a A$ & $0.31 \pm 0.10 \mathrm{bA}$ & $0.38 \pm 0.14 \mathrm{bA}$ \\
\hline
\end{tabular}

* The mean of four experimental runs, 20 insects in various developmental stages were used for each run;

$\dagger$ The values containing the same lower case letter in the same column are not different from each other, $P \leq 0.05$ (LSD test);

\# The values containing the same upper case letter in the same row are not different from each other, $P \leq 0.05$ (Kruskal-Wallis test);

$\S$ Control nutrient (boric acid free).

While B and B-containing compounds do not have a repellent effect (Maistrello et al., 2002), it is known that they can be toxic depending on the the rate of consumption and interaction with nutrients (Büyükgüzel \& İçen, 2004; Büyükgüzel \& Kalender, 2007). As a result of the pre-feeding experiments, it was found that $300 \mathrm{mg} / \mathrm{L}$ is the most effective BA concentration for $D$. melanogaster to complete its development and reach the adult stage.

Table 2. Protein carbonyl (PCO) levels in various developmental stages of Drosophila melanogaster raised with artificial nutrient containing various concentrations of boric acid

\begin{tabular}{|c|c|c|c|c|c|c|c|}
\hline \multirow{3}{*}{$\begin{array}{l}\text { Boric acid } \\
\text { (mg/Liter) }\end{array}$} & \multicolumn{7}{|c|}{$\begin{array}{l}\text { PCO }(\text { nmol/mg protein })^{*} \\
\left(\text { Mean }^{ \pm} \pm \mathrm{S} . \mathrm{E}\right)^{\dagger \#}\end{array}$} \\
\hline & \multirow{2}{*}{ Third stage larvae } & \multirow{2}{*}{\multicolumn{2}{|c|}{ Pupae }} & \multicolumn{4}{|c|}{ Adult } \\
\hline & & & & Female & & Male & \\
\hline $0.0^{\S}$ & $2.96 \pm 0.79 \quad a A$ & $6.35 \pm 1.23$ & $\mathrm{aAB}$ & $11.27 \pm 2.56$ & $\mathrm{aAB}$ & $31.85 \pm 8.63$ & $\mathrm{aB}$ \\
\hline 10 & $27.33 \pm 7.00 \quad a b A$ & $14.45 \pm 4.50$ & $\mathrm{aA}$ & $19.46 \pm 3.75$ & $\mathrm{aA}$ & $10.67 \pm 6.34$ & $a b A$ \\
\hline 100 & $25.74 \pm 9.16 \quad a b A B$ & $9.80 \pm 0.60$ & $\mathrm{aA}$ & $37.40 \pm 5.32$ & $\mathrm{aB}$ & $13.99 \pm 1.69$ & $a b A B$ \\
\hline 200 & $39.11 \pm 11.96 \quad a b A$ & $24.81 \pm 12.79$ & $\mathrm{aA}$ & $28.88 \pm 9.10$ & $\mathrm{aA}$ & $13.37 \pm 3.12$ & $a b A$ \\
\hline 300 & $52.50 \pm 17.61 \mathrm{bA}$ & $19.26 \pm 3.44$ & $\mathrm{aA}$ & $120.88 \pm 34.15$ & $\mathrm{bB}$ & $69.11 \pm 21.47$ & $\mathrm{cA}$ \\
\hline
\end{tabular}


Radiation, viruses, ultraviolet light, products of fossil fuels combustion, cigarette smoke, infection, stress, byproducts or final products generated during normal metabolic activity, some chemicals and substances such as insecticides are known to be free radical sources (Sarıkaya et al., 2012). It is known that MDA and PCO levels change in insects due to free radicals and overall oxidative stress (Wang et al., 2001). MDA and PCO levels in midgut cells and adipose tissue of Galleria mellonella L., 1758 increased and the insect underwent oxidative stress in the studies conducted using substances such as $\alpha$-solanine, ornidazole, gemifloxacin and niclosamide which is an anthelmintic antibiotic (Büyükgüzel et al., 2013; Erdem et al., 2013; Vuran et al., 2013; Büyükgüzel \& Kayaoğlu, 2014). Furthermore, nutrient components induce ROS generation in insects interacting with each other or substances added to the nutrient. Sugars added to Drosophila's nutrient such as galactose increase the level of MDA and decrease SOD activity (Jordens et al., 1999). The ROS produced in nutrients change toxicity depending on nutrient consumption of insect larvae (Cohen \& Crittenden, 2004). It has been observed that xanthotoxin, which is an allelochemical, increases MDA and PCO levels and decreases GST activity in G. mellonella (Erdem \& Büyükgüzel, 2015). While the mechanism of pathophysiological action of BA and some of B-containing compounds in insects is not known exactly, it is known that they induce the production of $\mathrm{O}_{2}$ radicals transferring electron to the molecular oxygen (Jolly, 1991). In this experiment, MDA level increased four times in third stage larvae raised with nutrient containing $300 \mathrm{mg} / \mathrm{L} \mathrm{BA}$ compared to the control group and reached $0.41 \pm 0.05 \mathrm{nmol} / \mathrm{mg}$, and the level of PCO increased about 17 times and reached $52 \pm 18 \mathrm{nmol} / \mathrm{mg}$ protein. A similar situation was observed in females and males raised with nutrients containing high concentrations of BA; the level of MDA increased nine times in males and seven times in females compared to the control group and the level of PCO increased to $120 \pm 34$ and $69 \pm 21 \mathrm{nmol} / \mathrm{mg}$ of protein, respectively (Tables $1 \& 2$ ). The accumulation of $B$ added to the nutrient in tissues varies depending on the development stage and age (Massie, 1994). The decrease observed in the level of MDA during the development process from larva stage to adult stage in the study shows similarity to previous studies. Drosophila larvae stop feeding towards the end of third stage (Lozinsky et al., 2012). The decrease in the level of MDA in the pupae indicates that BA accumulation is at the lowest level in this stage due to feeding cessation and perhaps due to the decrease in potential oxidative damage. A similar situation is observed in the level of PCO, a variation was seen between the developmental stages of insects. It is known that insecticides in particular cause oxidative stress effecting lipid, carbohydrate and protein levels in insects (Damien et al., 2004). For instance, the level of PCO is higher in males compared to females of Drosophila which were allowed to feed on high concentrations of S-nitrosoglutathione (Lozinsky et al., 2012). It is believed that BA used as an insecticide might cause changes in nutritional physiology of insects in association with excessive chemical intake due to the stimulation of nutrient intake, and oxidative damage in tissues. In this study, the increased levels of MDA and PCO proves that BA can cause cell damage in insects.

Table 3. Glutathione S-transferase (GST) activities in various developmental stages of Drosophila melanogaster raised with artificial nutrient containing various concentrations of boric acid

\begin{tabular}{|c|c|c|c|c|}
\hline \multirow{3}{*}{$\begin{array}{l}\text { Boric acid } \\
\text { (mg/Liter) }\end{array}$} & \multicolumn{4}{|c|}{$\begin{array}{c}\text { GST }(\text { nmol/mg protein/min) } \\
\left(\text { Mean }^{*} \pm \text { S.E }\right)^{\dagger \#}\end{array}$} \\
\hline & \multirow{2}{*}{ Third stage larvae } & \multirow{2}{*}{ Pupae } & \multicolumn{2}{|c|}{ Adult } \\
\hline & & & Female & Male \\
\hline $0.0^{\S}$ & $0.36 \pm 0.01 \mathrm{aA}$ & $0.52 \pm 0.28 \mathrm{aA}$ & $0.15 \pm 0.02 a A$ & $0.21 \pm 0.03 \quad a A$ \\
\hline 10 & $0.54 \pm 0.03 b A$ & $0.44 \pm 0.16 \quad a A B$ & $1.17 \pm 0.21 \mathrm{bA}$ & $0.15 \pm 0.01 \quad a B$ \\
\hline 100 & $0.56 \pm 0.05 b A$ & $0.35 \pm 0.13 \mathrm{aA}$ & $0.45 \pm 0.14 \mathrm{acA}$ & $0.33 \pm 0.04 \quad a A$ \\
\hline 200 & $0.64 \pm 0.04 \mathrm{bA}$ & $1.05 \pm 0.20 \mathrm{aA}$ & $0.68 \pm 0.11 \mathrm{cA}$ & $0.57 \pm 0.07 \mathrm{abA}$ \\
\hline 300 & $0.50 \pm 0.05 a b A$ & $1.80 \pm 0.74 b B$ & $0.75 \pm 0.10 \mathrm{bcAB}$ & $0.87 \pm 0.32 \mathrm{bAE}$ \\
\hline
\end{tabular}


The basic mechanism which enables insects to adapt to the environment is the common phenomenon of enzyme induction (Wu \& Miyata, 2005). GST, a detoxification enzyme, is an important indicator of oxidative stress (Otitoju \& Onwurah 2007). It is known that BA causes oxidative damage in midgut epithelial tissues of Blatella germanica L., 1767 adults and thus GST activity increases (Habes et al., 2006). It was found that the high resistance to synthetic pyrethroid observed is associated with the increase in GST activity in Spodoptera littoralis Boisduval, 1833 (Lagadic et al., 1993). Also, it was found that the activities of GST enzyme increase in direct proportion to increased resistance to insecticides such as chlorpyrifos, carbamate, and deltamethrin in S. littoralis populations (Hadim, 2008). It was observed that the antioxidant defense system of $D$. melanogaster is highly responsive increasing the activities of reduced glutathione (GSH), SOD, CAT, GR and GST (Özata, 2006). Studies of G. mellonella showed that the activities of antioxidant systems of SOD, CAT, GST and GPx significantly change in parallel with the increased levels of MDA and PCO in hemolymph and adipose tissue due to increased BA concentrations (Hyršl et al., 2007; Büyükgüzel et al., 2013; Büyükgüzel \& Kayaoğlu, 2014). In our study, GST activity in insects raised with nutrient containing high concentrations of BA significantly increased compared to the control group (Table 3). It is determined that the increase in GST activity is associated with insecticide resistance in studies conducted on cockroaches, domestic mosquitos and agricultural vermin. Particularly in studies conducted using chlorinated hydrocarbon insecticides (e.g. DDT), it was determined that GST activity increases in insects (Vontas et al., 2000; Rakotondravelo et al., 2006). It was found that there are different GST classes responsible for the elimination of oxidative stress in midgut (delta, epsilon, sigma, theta and omega zeta) of the third stage $D$. melanogaster larva, and most of the GST in midgut belongs to the delta and epsilon classes (Li et al., 2008). An increase was observed in GST activity against oxidative stress in pupa and adult stages of $D$. melanogaster when oxadiazole and 1-chloro-2,4-dinitrobenzene are used as herbicides (Scott et al., 1990). In our study, the highest BA concentrations tested on $D$. melanogaster significantly increased (three times) GST activity in pupae compared to the control. Although more detailed experiments are required on this point, the activity of this enzyme might have increased in parallel with the decrease in the level of GSH. GSH is the cofactor of this enzyme, and eliminates harmful effects of other free radicals and some of the organic and inorganic peroxides conjugating them (Dandapat et al., 2003). The increase in the level of this enzyme might be due to BA or metabolic products acting as oxidants and accelerating the production of free radicals thus causing oxidative stress in larvae. Particularly 200 and $300 \mathrm{mg} / \mathrm{L} \mathrm{BA}$ increased the GST activity approximately 2.5 and four times in adult males compared the control nutrient, respectively. Relatively resistant individuals might have been produced due to the resistance mechanism in Drosophila males. Also, the fact that the level of MDA increased in pupae and adult males raised with this nutrient about 10 times more than females corroborates this opinion. It is clearly seen in our study that BA causes changes in the levels of MDA and PCO, which are indicators of oxidative stress, and in the activity of GST, which is an important detoxification enzyme.

Table 4. Malondialdehyde (MDA) and protein carbonyl (PCO) levels and glutathione S-transferase (GST) activity in females and men raised with boric acid and then allowed to feed on boric acid for $10 \mathrm{~d}$

\begin{tabular}{|c|c|c|c|c|c|c|}
\hline \multirow{2}{*}{$\begin{array}{c}\text { Boric } \\
\text { acid } \\
\text { (mg/Liter) }\end{array}$} & \multicolumn{2}{|c|}{$\begin{array}{l}\text { MDA }(\text { nmol/mg protein })^{*} \text { pre } \\
\quad\left(\text { Mean }^{\prime} \pm \text { S.E }\right)^{\dagger \#}\end{array}$} & \multicolumn{2}{|c|}{$\begin{array}{l}\mathrm{PCO}\left(\mathrm{nmol}^{*} \mathrm{mg} \text { protein }\right) \\
\quad\left(\text { Mean }^{*} \pm \mathrm{S} . \mathrm{E}\right)^{\dagger \#}\end{array}$} & \multicolumn{2}{|c|}{$\begin{array}{c}\text { GST }(\text { nmol/mg protein/min) } \\
\left(\text { Mean }^{*} \pm \text { S.E }\right)^{\dagger \#}\end{array}$} \\
\hline & Female $^{*}$ & Male $^{\#}$ & Female $^{*}$ & Male $^{*}$ & Female $^{*}$ & Male $^{*}$ \\
\hline $0.0^{\S}$ & $0.03 \pm 0.01 \mathrm{aA}$ & $0.05 \pm 0.02 \mathrm{aA}$ & $3.08 \pm 0.88 \mathrm{aA}$ & $2.89 \pm 1.04 \mathrm{aA}$ & $0.67 \pm 0.26 \mathrm{aA}$ & $1.00 \pm 0.39 a \mathrm{aA}$ \\
\hline 10 & $0.08 \pm 0.03 \mathrm{abA}$ & $0.07 \pm 0.02 a b A$ & $4.47 \pm 0.47 \mathrm{aA}$ & $2.14 \pm 0.16 \mathrm{aB}$ & $2.14 \pm 0.42 b A$ & $1.83 \pm 0.39 \mathrm{aA}$ \\
\hline 100 & $0.04 \pm 0.02 a A$ & $0.26 \pm 0.11 \mathrm{bA}$ & $8.97 \pm 2.85 \mathrm{aA}$ & $2.22 \pm 0.22 \mathrm{aB}$ & $1.18 \pm 0.12 \mathrm{abA}$ & $5.78 \pm 1.26 b B$ \\
\hline 200 & $0.07 \pm 0.02 a b A$ & $0.17 \pm 0.05 a b A$ & $8.85 \pm 2.56 \mathrm{aA}$ & $8.67 \pm 2.13 \mathrm{aA}$ & $1.90 \pm 0.11 b A$ & $2.41 \pm 0.40 \mathrm{aA}$ \\
\hline 300 & $0.12 \pm 0.01 \mathrm{bA}$ & $0.08 \pm 0.02 a b A$ & $29.01 \pm 6.86 \mathrm{bA}$ & $20.91 \pm 5.10 \mathrm{bA}$ & $1.65 \pm 0.15 b A$ & $1.75 \pm 0.26 \mathrm{aA}$ \\
\hline
\end{tabular}

\footnotetext{
* The mean of four experimental runs, 20 insects in various developmental stages were used for each run;

$\dagger$ The values containing the same lower case letter in the same column are not different from each other, $P \leq 0.05$ (LSD test);

\# For each parameter: The values containing the same upper case letter in the same row are not different from each other, $P \leq 0.05$ (Mann-Whitney test);

$\S$ Control nutrient (boric acid free);

* Adults raised with boric acid and then allowed to feed on boric acid for $10 \mathrm{~d}$.
} 
It has been reported that tissue resistance to spontaneous autoxidation decreases with age, peroxidation more frequently occurs in old tissues than normal tissues and antioxidants may decrease the frequency but cannot delay the aging process. However, it has been found that the levels of endogenous antioxidants acting as a means of defense against antioxidant damage does not change, decrease or increase with age (Yüzüak, 2008). It has been reported that high gravity ( 3 and $5 \mathrm{~g}$ ) does not affect enzyme activities (SOD and CAT) in two, four and six-week-old D. melanogaster (Le Bourg et al., 2000). In our study, no significant difference was observed between males and females (10 d) in terms of the level of MDA in the feeding experiments conducted using the control nutrient and nutrient containing various concentrations of $\mathrm{BA}$ after reaching adult stage (Table 4). Prooxidative changes during the aging process may not induce pathology as in our study (Büyükgüzel \& Akın, 2014). It was seen that continuing intake of the nutrient containing $300 \mathrm{mg} / \mathrm{L} \mathrm{BA}$ after reaching the adult stage significantly (nine times in females and seven times in males) increases the level of PCO in adults compared to the control. It was shown in the previous studies that the level of oxidatively modified proteins increase with age (Büyükgüzel, 2013), which is similar to our findings. The GST activity in Drosophila is associated with the length of life and nutrient intake (Toba \& Aigaki, 2000). The GST activity in Drosophila males and females rose as S-nitrosoglutathione increased starting from the larva stage (Lozinsky et al., 2012). In our study, the GST activity increased to $1.65 \pm 0.15 \mathrm{nmol} / \mathrm{mg}$ protein $/ \mathrm{min}$ in females and $1.75 \pm 0.26$ in males. The increased enzyme activity is believed to have a protective role in insects. This statistically non-significant increase in males indicates that oxidative stress might have reached the level the enzyme cannot counteract and the enzyme itself might have been damaged.

Table 5. MDA and PCO levels and GST activity in females and men raised with boric acid and then allowed to feed on boric acidfree diet for $10 \mathrm{~d}$

\begin{tabular}{|c|c|c|c|c|c|c|}
\hline \multirow{2}{*}{$\begin{array}{c}\text { Boric } \\
\text { acid } \\
\text { (mg/Liter) }\end{array}$} & \multicolumn{2}{|c|}{$\begin{array}{l}\text { MDA }\left(\mathrm{nmol}^{*} / \mathrm{mg} \text { protein }\right) \\
\quad\left(\text { Mean }^{*} \pm \mathrm{S} . \mathrm{E}\right)^{\dagger \#}\end{array}$} & \multicolumn{2}{|c|}{$\begin{array}{l}\text { PCO (nmol/mg protein) } \\
\quad\left(\text { Mean }^{*} \pm \text { S.E }\right)^{\dagger \#}\end{array}$} & \multicolumn{2}{|c|}{$\begin{array}{c}\text { GST }\left(\mathrm{nmol} /{ }^{*} \text { g protein/min) }\right. \\
(\text { Mean } \pm \text { S.E })^{\dagger \#}\end{array}$} \\
\hline & Female $^{*}$ & Male & Female $^{*}$ & Male & Female $^{*}$ & Male $^{*}$ \\
\hline $0.0^{\S}$ & $0.03 \pm 0.01 \mathrm{aA}$ & $0.05 \pm 0.01 \mathrm{aA}$ & $3.08 \pm 0.88 \mathrm{aA}$ & $2.89 \pm 1.04 \mathrm{aA}$ & $0.67 \pm 0.26 \mathrm{aA}$ & $1.00 \pm 0.39 \mathrm{aA}$ \\
\hline 10 & $0.10 \pm 0.02 a A$ & $0.04 \pm 0.01 \mathrm{aA}$ & $4.31 \pm 0.32 \mathrm{abA}$ & $2.28 \pm 0.48 \mathrm{aB}$ & $1.41 \pm 0.16 a b A$ & $1.92 \pm 0.61 \mathrm{abA}$ \\
\hline 100 & $0.10 \pm 0.02 \mathrm{aA}$ & $0.11 \pm 0.03 \mathrm{aA}$ & $2.92 \pm 0.51 \mathrm{aA}$ & $2.54 \pm 0.54 \mathrm{aA}$ & $3.35 \pm 1.24 \mathrm{bA}$ & $3.62 \pm 1.03 \mathrm{bA}$ \\
\hline 200 & $0.10 \pm 0.02 a A$ & $0.09 \pm 0.03 \mathrm{aA}$ & $4.82 \pm 1.31 \mathrm{abA}$ & $4.64 \pm 0.54 \mathrm{aA}$ & $2.79 \pm 0.71 \mathrm{abA}$ & $1.50 \pm 0.36 \mathrm{abA}$ \\
\hline 300 & $0.07 \pm 0.02 \mathrm{aA}$ & $0.22 \pm 0.12 \mathrm{aA}$ & $7.75 \pm 2.36 \mathrm{bA}$ & $13.16 \pm 4.07 \mathrm{bA}$ & $2.28 \pm 0.41 \mathrm{abA}$ & $4.12 \pm 0.89 \mathrm{bA}$ \\
\hline
\end{tabular}

\footnotetext{
* The mean of four experimental runs, 20 insects in various developmental stages were used for each run;

$\dagger$ The values containing the same lower case letter in the same column are not different from each other, P $\leq 0.05$ (LSD test);

${ }^{\#}$ For each parameter: The values containing the same upper case letter in the same row are not different from each other, $\mathrm{P} \leq 0.05$ (Mann-Whitney test);

$\S$ Control nutrient (boric acid free);

$¥$ Adults raised with boric acid and then allowed to feed on boric acid for $10 \mathrm{~d}$.
}

Antioxidant enzyme activity changes in females and males after the Drosophila larvae, exposed to xenobiotics such as sodium nitroprusside, S-nitrosoglutathione and potassium ferrocyanide, reached the adult stage (Lozinsky, 2013). Another study determined that wild type Drosophila Oregon males (85 d) lived longer than the males with atrophied wings (56 d) and age-related changes in their CAT activity were similar, and GR activity (between 10 and $40 \mathrm{~d}$ ) and the level of total glutathione first increased then decreased suddenly (Fışkın et al., 1994). Ay \& Yorulmaz (2008) determined that the levels of esterase and GST increased in the bifenthrin resistant Tetranychus urticae C. L. Koch, 1836 population compared to the initial population. Our study showed that feeding on high concentrations of BA until the adult stage and then control nutrient for $10 \mathrm{~d}$ significantly increased the level of PCO (2.5 times in females and 4.5 times in male) and the activity of GST (2.28 \pm 0.41 in females; $4.12 \pm 0.89 \mathrm{nmol} / \mathrm{mg}$ protein/min in males) (Table 5). The change in the accumulation of B in Drosophila depending on age (Massie, 1994) and the amount of nutrient observed in our study indicates that antioxidant enzyme activity will improve due to decreased oxidation by the elimination of BA after reaching the adult stage. 


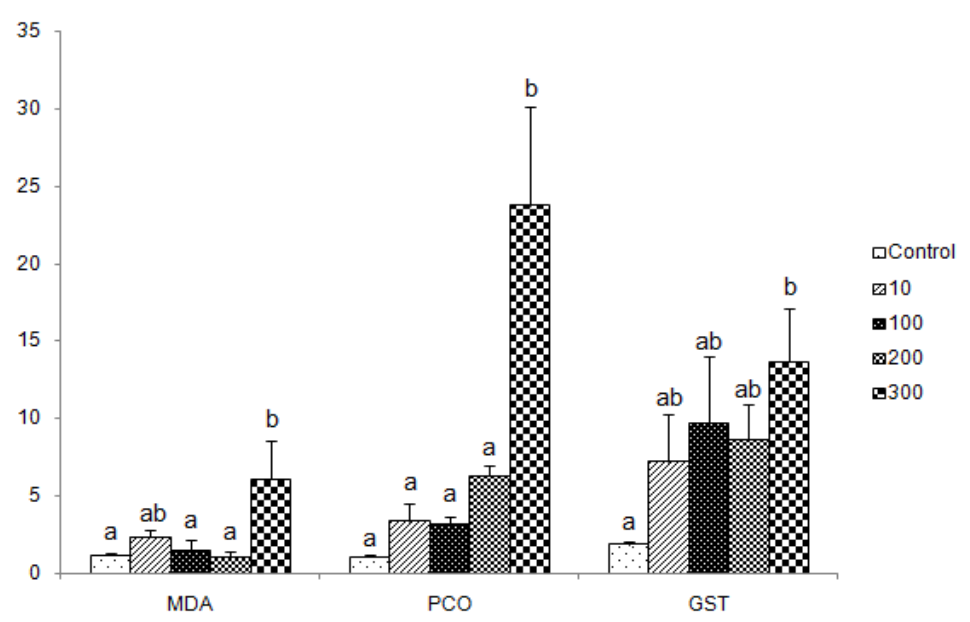

Figure 2. MDA and PCO levels and GST activity in eggs of adult females raised with boric acid and then allowed to feed on boric acid for $10 \mathrm{~d}$.

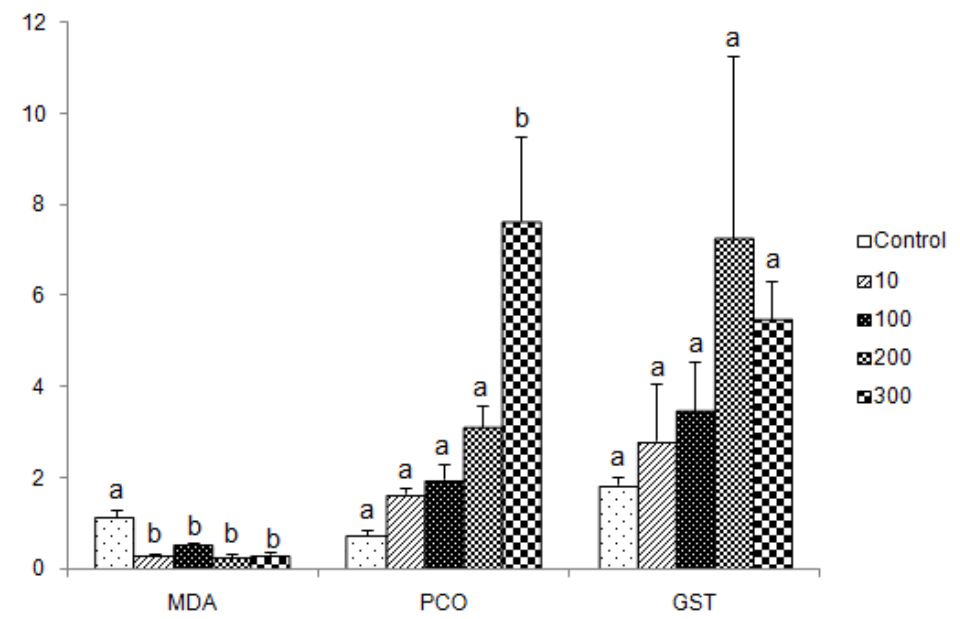

Figure 3. MDA and PCO levels and GST activity in eggs of adult females raised with boric acid and then allowed to feed on boric acid-free diet for $10 \mathrm{~d}$.

Drosophila melanogaster adjusts the number of its eggs depending on its nutrition in order not to endanger the species (Partridge et al., 1987). Vitellogenin (egg yolk protein) and adipose tissue used for larva and adult development are synthesized in hemolymph and stored in oocyte in Drosophila (De Man et al., 1981). Changes in the protein content of hemolymph, adipose tissue and ovary of Pyrrhocoris apterus L., 1758 can be caused by some nucleoside-derived synthetic insecticides (Gelbič \&Šula, 1990). BA is known to decrease protein, lipid and carbohydrate content of the ovary in cockroaches (Kilani-Morakchi et al., 2005). The best period for egg production in Drosophila is its first $10 \mathrm{~d}$ as an adult (Yeşilada \& Bozcuk, 1995). In our study, feeding on the highest concentration of BA during both larva and adult stages increased the level of MDA by about 5 times, the level of PCO about 31 times, and the activity of GST about 7 times in the eggs of females compared to the control (Figures 2 and 3 ). It is known that the maximum B accumulation occurs in the egg (Massie, 1994). The accumulation due to exposure to BA may have caused an increase in the levels of MDA and PCO which are indicators of oxidation in both larva and adult stages. It is believed that exposure to BA increases oxidative stress effecting biomolecules of insects, inhibiting vitellogenin synthesis, or due to oxidation of proteins in eggs. It is shown that these types of effects are associated with prooxidant and antioxidant systems in insects (Büyükgüzel, 2006). 
According to these findings, the increase in the levels of MDA and PCO in D. melanogaster due to BA exposure indicates that free oxygen radicals induce oxidative stress in cells. While low concentrations of BA were tolerated and the antioxidant defense mechanism was activated in a shorter time trying to prevent oxidative stress, the mechanism was not able to prevent oxidative stress in case of high concentrations of BA. It can be clearly seen that the effects of BA on the oxidant and antioxidant reactions in insects varies depending on the concentration of BA. It is shown that feeding on high concentrations of BA from the larva stage negatively effects insects and its detoxification capacity. Also, the use of low concentrations of BA as in the adult diet increased the levels of MDA and PCO and the activity of GST thus indicating that the antioxidant defense mechanism works. According to these results, low concentrations of BA may be added to the adult nutrient as an ingredient to improve the capacity of $D$. melanogaster adults, however, potential cell damages due to oxidative stress should be considered. This result is significant in terms of fighting target insects without harming the environment and non-target organisms, suggesting the use of low concentrations of BA, which is an inorganic insecticide less harmful than currently used insecticides. However, this oral feeding study was carried out in the laboratory, futher studies are needed to examine the use of BA in the field.

\section{Acknowledgments}

This study was conducted by Bulent Ecevit University, Graduate Education and Scientific Research as a research project supported by the Unit (BAP / 20111-10-06-10).

\section{References}

Ahmad, S., 1995. Oxidative stress from environmental pollutants. Archives of Insect Biochemistry and Physiology, 29: $135-157$.

Ali, A., R. D. Xue \& D. R. Barnard, 2006. Effects of sublethal exposure to boric acid sugar bait on adult survival, hostseeking, blood feeding behavior, and reproduction of Stegomyia albopicta. Journal of the American Mosquito Control, 22: 464-468.

Anonymous, 2004. Avrupa Perakendecileri Ürün Çalışma Grubu'nun Iyi Tarım Teknikleri Uygulamaları (EUREPGAP). Akdeniz Yaş Meyve Sebze İhracatçıları Birliği, ARGE Dış Ilişkileri Şube Müdürlüğü, 36 s.

Ay, R. \& S. Yorulmaz, 2008. "The evaluation of the esterase and glutathion s-transferase enzymes in two-spotted spider mite Tetranychus urticae Koch (Acarina: Tetranychidae) selected with bifenthrin, 419-424". Integrative Acarology Proceedings on the 6th European Association of Acarologists Congress (21-25 July, France) Proceedings, 491 pp.

Barbehenn, R. V. \& J. Stannard, 2004. Antioxidant defense of the midgut epithelium by the peritrophic envelope in caterpillars. Journal of Insect Physiology, 50: 783-790.

Büyükgüzel, K. \& E. İçen, 2004. Effects of gyrase inhibitors on the total protein content of Pimpla turionellae L. reared on an artificial diet. Journal of Entomological Science, 39 (1): 108-116.

Büyükgüzel, K., 2006. Malathion-induced oxidative stress in a parasitoid wasp: Effect on adult emergence, longevity, fecundity, oxidative and antioxidative response of the Pimpla turionellae. Journal of Economic Entomology, 99: 1225-1234.

Büyükgüzel, E. \& Y. Kalender, 2007. Penicillin-induced oxidative stress: effects on antioxidative response of midgut tissues in larval instars of G. mellonella. Journal of Economic Entomology, 100: 1533-1541.

Büyükgüzel, E., 2013. Protein oksidasyonun biyokimyasal ve moleküler mekanizması. Karaelmas Fen ve Mühendislik Dergisi, 3 (1): 40-51.

Büyükgüzel, E., K. Büyükgüzel, E. Erdem, Z. Adamski, P. Marciniak, K. Ziemnicki, E. Ventrella, L. Scrano \& S.A. Bufo, 2013. The influence of dietary $\alpha$-solanine on the waxmoth Galleria mellonella L. Archives of Insect Biochemistry and Physiology, 89 (4):1-10.

Büyükgüzel, E. \& R. Akın, 2014. Redoksa duyarlı sinyal iletiminde reaktif oksijen türlerinin (ROT) rolü. Karaelmas Fen ve Mühendislik Dergisi, 4 (2): 70-81.

Büyükgüzel, E. \& S. Kayaoğlu, 2014. Niklozamidin Galleria mellonella L. (Lepidoptera: Pyralidae)'nın bazı biyolojik ve fizyolojik özelliklerine etkisi. Türkiye Entomoloji Dergisi, 38 (1): 83-99.

Cisneros, J., J. A. Perez, D.I. Penagos, D. Goulson, Caballero, D. R. Cave \& T. Wiliams, 2002. Formulation of a nucleopolyhedrovirus with boric acid for control of Spodoptera frugiperda in maize. Biological Control, 23: 87-95. 
Cochran, D. G., 1995. Toxic effects of boric acid on the German cockroach. Experientia, 51: 561-563.

Cohen, A. C. \& P. Crittenden, 2004. Deliberately added and "cryptic" antioxidants in three artificial diets for insects. Journal of Economic Entomology, 97: 265- 272.

Damien, C., V. H. Chantal, S. Pirouz, F. H. Zerimech, J. Laurence \& M. H. Jean, 2004. Cellular impact of metal trace elements in terricolous lichen Diploschistes muscorum (Scop.) R. Sant-identification of oxidative stress biomarkers. Water Air Soil Pollution, 152: 55-69.

Dandapat, J., G. B. N. Chainy \& K. J. Rao, 2003. Improved post-larval production in giant prawn, Macrobrachium rosenbergii through modulation of antioxidant defense system by dietary vitamin-E. Indian Journal of Biotechnology, 2 (2): 195-202.

De Man, W., A. De Loof, T. Bries \& R. Huybrecths, 1981. Effect of absisic acid on vitellogenesis in Sarcophoga bulata. Entomologia Experimentalis et Applicata, 29: 259-267.

Durmuş, Y. \& K. Büyükgüzel, 2008. Biological and immune response of Galleria mellonella L. (Lepidoptera: Pyralidae) to sodium tetraborate. Journal of Economic Entomology, 101: 777-783.

EFSA, 2004. Opinion of the scientific panel on dietetic products, nutrition and allergies on a request from the commission related to the tolerable upper intake level of boron (sodium borate and boric acid) (Request $\mathrm{N}_{-}$ EFSAQ- 2003-018). European Food Safety Authority Journal, 80: 1-22.

Erdem, M., C. Küçük, E. Büyükgüzel \& K. Büyükgüzel, 2013. "The effect of gemifloxacin on hemoplymph oxidative and antioxidative response of Galleria mellonella L. (Lepidoptera: Pyralidae), 168". Drug Discovery and Therapy World Congress (3-6 June, USA) Proceedings, 226 pp.

Erdem, M. \& E. Büyükgüzel, 2015. The effects of xanthotoxin on the biology and biochemistry of Galleria mellonella L. (Lepidoptera: Pyralidae). Archives of Insect Biochemistry and Physiology, 89 (4): 193-203.

Espinoza-Navarro, O., H. Rodrignez, M. Rodrignez, E. Silva \& A. Luque, 2009. Alteraton of the reproductive patternsin Drosophila melanogaster by Effect of high concentrations of Boron on in vitro cultured medium. International Journal of Morphology, 27 (3): 765-770.

Evans, P., L. Lyras \& B. Halliwel, 1999. Measurement of protein carbonyls in human brain tissue. Methods in Enzymology, 300: 145-156.

Fışkın, K., S. Kandemir, D. Hamamcı, E. Yeşilada \& A. N. Bozcuk, 1994. Age-related changes in catalase, glutathione reductase activities, the amount of glutathione in total body of Oregon and vestigial Drosophila melanogaster. Archives of Gerontology and Geriatrics, 4: 85-90.

Ford, D. J., T. L. Propst, E. L. Stover, P. L. Strong \& F. J. Murray,1998. Adverse reproductive and developmental effects in xenopus from insufficient boron. Biological Trace Element Research, 66: 237-259.

Gelbič, I. \& J. Šula, 1990. Ovicidal and biochemical effects of hempa and a nucleoside analogue on Pyrrhocoris apterus (L.) (Het., Pyrrhocoridae). Journal Applied Entomology and Zoology, 109: 401-409.

Giordano, G., Z. Afsharinejad, M. Guizzetti, A. Vitalone, T. J. Kavanagh \& L. G. Costa, 2007. Organophosphorus insecticides chlorpyrifos and diazinon and oxidative stress in neuronal cells in a genetic model of glutathione deficiency. Toxicology and Applied Pharmacology, 219:181-189.

Gore, J. C., L. Zurek, R. G. Santangelo, S. M. Stringham, D. W. Watson \& C. Schal, 2004. Water solutions of boric acid and sugar for management of German cocroach populations in livestock production system. Journal of Economic Entomology, 97: 715-720.

Gülbahar, Ö., 2007. Protein oksidasyonun mekanizması, önemi ve yaşlılıkla ilgisi. Turkish Journal of Geriatrics, 10: 43-48.

Habes, D., S. Morakchi, N. Aribi, J. P. Farine \& N. Soltani, 2006. Boric acid toxicity to the German cockroach, Blattella germanica: Alterations in midgut structure, and acetylcholinestrease and glutathione S-transferase activity. Pesticide Biochemistry and Physiology, 84: 17-24.

Habig, W. H., M. J. Pabst \& W. B. Jakoby, 1974. Glutathione-s-transferases: the first enzymatic step in mercapturic acid formation. Journal of Biological Chemistry, 249: 7130-7139.

Hadim, N., 2008. Pamuk Yaprak Kurdu Spodoptera littoralis (Boisduval) (Lepidoptera: Noctuidae)'te İnsektisitlere Karşı Oluşan Direncin Biyokimyasal ve Moleküler Karakterizasyonu. Ankara Üniversitesi Biyoteknoloji Enstitüsü, (Basılmamış) Doktora Tezi, Ankara, $146 \mathrm{~s}$.

Hermes-Lima, M. \& T. Zenteno-Savín, 2002. Animal response to drastic changes in oxygen availability and physiological oxidative stress. Comparative Biochemistry and Physiology Part C: Toxicology, 133: 537-56. 
Hyršl, P., E. Büyükgüzel \& K. Büyükgüzel, 2007. The effects of boric acid-induced oxidative stress on antioxidant enzymes and survivorship in Galleria mellonella. Archives of Insect Biochemistry and Physiology, 66: 23-31.

Jain, S. K. \& S. N. Levine, 1995. Elevated lipid peroxidation and Vitamin E quinine levels in heart ventricles of streptozoticin-treated diabetic rats. Free Radical Biology and Medicine, 18: 337-341.

Jordens, R. G., M. D. Berry, C. Gillott \& A. A. Boulton, 1999. Prolongation of life in an experimental model of ageing in Drosophila melanogaster. Neurochemical Research, 24 (2): 227-233.

Jolly, W. L., 1991. Modern Inorganic Chemistry. $2^{\text {nd }}$ Ed, McGraw-Hill, New York, 655 pp.

Kaya, B., H. Çetin, S. Kocaoğlu \& E. Demir, 2009. Farklı Oranlardaki Sentetik Pyretroit ve Piperonyl Butoxide (PBO) Karışımlarının Drosophila melanogaster Üzerindeki İnsektisidal ve Genotoksik Etkilerinin Araştırılması. Tübitak, TBAG, 107T189, $49 \mathrm{~s}$.

Keser, D., 2010. Aspirin ve Asetaldehitin Drosophila melanogasterĩn Bazı Gelişimsel Özellikleri Üzerine Etkileri. Kocaeli Üniversitesi Fen Bilimleri Enstitüsü Biyoloji Anabilim Dalı, (Basılmamış) Yüksek Lisans Tezi, Kocaeli, $68 \mathrm{~s}$.

Kilani-Morakchi, S., N. Aribi, J. P. Farine, C. Everaerts \& N. Soltani, 2005. Effets de l'acide borique sur les profiles d'hydrocarbures cuticulaires chez un insecte à intérêt médical, Blattella germanica (Dictyoptera: Blattellidae). Journal of the Algerian Chemical Society, 15 (2): 225-231.

Krishnan, N. \& D. Kodrik, 2006. Antioxidant enzymes in Spodoptera littoralis (Boisduval): Are they enhanced to protect gut tissues during oxidative stress? Journal of Insect Physiology, 52: 11-20.

Lagadic, L., A. Cuany, J. B. Bergé \& M. Echaubard, 1993. Purification and Partial Characterization of Glutathione Stransferase from insecticide-resistant and lindane-inducced susceptible Spodoptera littoralis (Boisd.) larvae. Insect Biochemistry and Molecular Biology, 23 (4): 467-474.

Le Bourg, E., N. Minois, P. Bullens \& P. Baret, 2000. A mild stress due to hypergravity exposure at young age increases longevity in Drosophila melanogaster males. Biogerontology, 1 (2): 145-155.

Lesch, C., A. Goto, M. Lindgren, G. Bidla, M. S. Dushay \& U. Theopold, 2007. A role for Hemolectin in coagulation and immunity in Drosophila melanogaster. Developmental and Comparative Immunology, 31: 1255-1263.

Levine, R. L., J. A. Williams, E. R. Stadtman \& E. Shacter, 1994. Carbonyl assays for determination of oxidatively modified proteins. Methods in Enzymology, 233: 346-357.

Li, Y. M., H. Y. E. Chan, X. Q. Yao, Y. Huang, \& Z. Y. Chen, 2008. Green tea catechins and broccoli reduve fatinduced mortality in Drosophila melanogaster. Journal of Nutritional Biochemistry, 19: 376-383.

Lowry, O. H., N. I. Rosebroug, A. L. Farr \& R. J. Randall, 1951. Protein measurement with the Folin phenol reagent. Journal of Biological Chemistry, 19: 265.

Lozinsky, O. V., 2013. Aconitase and developmental end points as early indicators of cellular toxicity induced by xenobiotics in Drosophila melanogaster. Iranian Journal of Toxicology, 8 (24): 998-1003.

Lozinsky, O. V., O. V. Lushchak, N. I. Kryshchuk, N. Y. Shchypanska, A. H. Riabkina, S. V. Skarbek, I. V. Maksymiv, J. M. Storey, K. B. Storey \& V. I. Lushchak, 2012. S-Nitrosoglutathione-induced toxicity in Drosophila melanogaster: Delayed pupation and induced mild oxidative/nitrosative stress in eclosed flies. Comparative Biochemistry and Physiology Part A: Molecular and Integrative Physiology, 64 (80): 162- 70.

Maistrello, L., G. Henderson \& R. A. Laine, 2002. Comparative effects of vetiver oil, nootkatone and disodium octaborate tetrahydrate on Coptotermes formosanus and its symbiotic fauna. Pest Management Science, 59: 58-68.

Massie, H., 1994. Effect of dietary boron on the aging process. Environmental Health Perspectives, 102 (7): $45-48$.

Missirlis, F., S. Rahlfs, N. Dimopoulos, H. Bauer, K. Becker, A. Hilliker \& J. P. Phillips, 2003. A putative glutathione peroxidase of Drosophila encodes thioredoxin peroxidase that provides resistance against oxidative stress but fails to complement a lack of catalase activity. Journal of Biological Chemistry, 384 (3): 463-472.

Otitoju, O. \& I. N. E. Onwurah, 2007. Glutathione S-transferase (GST) activity as a biomarker in ecological risk assessment of pesticide contaminated environment. African Journal of Biotechnology, 6: 1455-1459.

Özata, L., 2006. Bazı Tekstil Boyalarının Drosophila melanogaster Üzerine Toksik Ve Genotoksik Etkilerinin Araştırılması. İnönü Üniversitesi Fen Bilimleri Enstitüsü, (Basılmamış) Doktora Tezi, Malatya, 87 s.

Park, M., Q. Li, N. Shcheynikov, W. Zeng \& S. Muallern, 2004. NaBC1 is a ubiquitous electrogenic Na1-coupled borate transporter essential for cellular boron homeostasis and cell growth and proliferation. Molecular Cell,16: 331-341.

Partridge, L., A. Hoffman \& S. Jones, 1987. Male size and mating success in Drosophila melanogaster and Drosophila pseudoobscura under field conditions. Animal Behaviour, 35: 468-476. 
Peric-Mataruga, V., D. Blagojevic, M. B. Spasic, J. Ivanovic \& M. Jankovic-Hladni, 1997. Effect of the host plant on the antioxidative defence in the midgut of Lymantria dispar L. caterpillars of different population origins. Journal of Insect Physiology, 43: 101-106.

Rakotondravelo, M. L., T. D. Anderson, R. E. Charlton \& K. Y. Zhu, 2006. Sublethal Effects of Three Pesticides on Activities of Selected Target and Detoxification Enzymes in the Aquatic Midge, Chironomus tentans (Diptera: Chironomidae). Archives of Environmental Contamination and Toxicology, 51: 360-366.

Rowe, R. I., C. Bouzan, S. Nabili \& C. D. Eckart, 1998. The response of trout and zebrafish embryos to low and high boron concentrations is u-shaped. Biological Trace Element Research, 66: 261-270.

Sarıkaya, R., K. Erciyas, A. F. Erciyas, S. Ay, M. İ. Kara \& U. Sezer, 2012. Antioksidanların (Bor ve Thymoqinone) Antigenotoksik Etkilerinin Drosophila Somatik Mutasyon ve Rekombinasyon Testi ile Araştırılması. Tübitak, Araştırma Projesi, 210T159, $38 \mathrm{~s}$.

Scott, J. G., D. G. Cochran \& B. D. Siegfried, 1990. Insecticide toxicity, synergism and resistance in the German cockroach (Dictyoptera: Blattellidae). Journal of Economic Entomology, 83: 1698-1703.

SPSS, 1997. User's Manual, Version 10. SPSS Inc., Chicago, IL.

Taşkın, V., K. Küçükakyüz, T. Arslan, B. Çöl \& B. Taşkın Göçmen, 2007. The biochemical basis of insecticide resistance and determination of esterase enzyme patterns by using PAGE in field collected populations of Drosophila melanogaster from Muğla province of Turkey. Journal of Cell and Molecular Biology, 6 (1): 31-40.

Toba, G. \& T. Aigaki, 2000. Disruption of the microsomal glutathione S-transferase-like gene reduces life span of Drosophila melanogaster. Gene, 253 (2): 179-187.

Uysal, H. \& T. Şişman, 2003. Genetik Laboratuvar Kılavuzu. Atatürk Üniversitesi Fen Fakültesi, Biyoloji Bölümü Yayını, Erzurum.

Vasseur, P. \& C. Leguille, 2004. Defense systems of benthic invertebrates in response to environmental stressors. Environmental Toxicology, 19: 433-436.

Vontas, J. G., A. A. Enayati, G. J. Small \& J. Hemingway, 2000. A simple biochemical assay for glutathione stransferase activity and its possible field application for screening glutathione s-transferase- based insecticide resistance. Pesticide Biochemistry and Physiology, 68: 184-192.

Vontas, J. G., G. J. Small \& J. Hemingway, 2001. Glutathione S-transferases as antioxidant defence agents confer pyrethroid resistance in Nilaparvata lugens. Biochemical Journal, 357: 65-72.

Vuran, E., M. Erdem, E. Büyükgüzel \& K. Büyükgüzel, 2013. "The effect of Ornidazole on biological and biochemical parameters of Galleria mellonella L., 153". Drug Discovery and Therapy World Congress (3-6 June, USA) Proceedings, $226 \mathrm{pp}$.

Wang, Y., L. W. Oberley \& D. W. Murhammer, 2001. Evidence of oxidative stres following the viral infection of two lepidopteran insect cell lines. Free Radical Biology and Medicine, 31: 1448-1455.

Wu, G. \& T. Miyata, 2005. Susceptibilities to methamidophos and enzymatic characteristics in 18 species of pest insects and their natural enemies in crucifer vegetable crops. Pesticide Biochemistry and Physiology, 82: 79-93.

Xue, R. D. \& D. R. Barnard, 2003. Boric acid bait kills adult mosquitoes (Diptera: Culicidae). Journal of Economic Entomology, 96:1559-1562.

Xue, R. D., D. L. Kline, A. Ali \& D. R. Branard, 2006. Application of boric acid baits to plant foliage for adult mosquito control. Journal of the American Mosquito Control, 22: 497-500.

Yang, L. K., H. N. Nigg, S. Fraser, E. Burns \& S. E. Simpson, 2000. Midgut proteinase types and sodium tetraborate effects on midgut proteinase activities of female Anastrepha suspensa (Diptera: Tephritidae). Annals of the Entomological Society of America, 93: 602-609.

Yeşilada, E. \& A. N. Bozcuk, 1995. The effects of ABA and kinetin on the fecundity of Drosophila melanogaster. Turkish Journal of Biology, 19: 37-44.

Yüzüak, H., 2008. Yaşlanma Sürecinde Pankreas Dokusunda NOX, MDA, GSH Düzeyleri ve Melatoninin Etkisi. Gazi Üniversitesi Sağlık Bilimleri Enstitüsü Fizyoloji Anabilim Dalı, (Basılmamış) Yüksek Lisans Tezi, Ankara, 95 s. 